\title{
ÉSVAGYÍTÁS
}

HORVÁTH DÓRA - MITEV ARIEL

\section{VENDÉGSZERKESZTŐI GONDOLATVEGYÍTÉS A KVALITATÍV KÜLÖNSZÁMHOZ}

\section{ÉS VAGY !?}

Piac ÉS maraton,

Mindenhatóság VAGY gondolatfüzés.

ÉS akkor mi van?

Minden szobát nyit egy kulcs.

(forrás: jelen szám cikkeiben megjelenő kulcsszavak)

És S és VAGY, vagy És vagy VAGY? Két egymással ellentétes kötőszó, melyek általában egymást kizárva jelennek meg, együttállás, illetve kizárólagosság viszonyát fejezik ki. A kvalitatív kutatás módszertani kérdéseit kutatva azt a következtetést vonhatjuk le, hogy e két kötőszó nem zárja ki egymást, beszéljünk a kvalitatív kutatás kapcsolódási pontjairól, megközelítéseiről, a kutatói szerepekröl, az interpretációról.

ÉS és VAGY olyannyira nem zárják ki egymást, hogy az Olvasó a kvalitatív kutatási módszertanokkal foglalkozó Vezetéstudomány tematikus szám második részét tartja a kezében, mivel a téma számos tudományág eltérő álláspontot képviselő kutatóját inspirálta újabb és újabb hozzájárulásokra. A két lapszámban nem éles vita, hanem inter- és transzdiszciplináris együttmüködés első lépései bontakoztak ki. Célunk a folytatás, a párbeszéd, a módszertani fejlesztés továbbvitele, melynek egyik vezető fóruma lehet a továbbiakban is a Vezetéstudomány folyóirat.

A Vezetéstudomány e második kvalitatív tematikájú különszámában megjelenő cikkek azzal a dilemmával foglalkoznak, hogy milyen viszonyban lehetnek egymással különbözö megközelítésü kutatási módszertanok, hogyan gazdagíthatják kvalitatív megközelítések a standard megkérdezés módszereit, hogyan hozhatók össze különböző diszciplínák eltérően képzett képviselői egy kérdés megválaszolására, hogyan értelmezhető és értékelhető a kutató megfigyelő szerepének hatóköre, a kvalitatív kutatás résztvevőitől milyen mértékü hozzájárulásokat várunk.

Letenyei László, Hoffer Ádám és Horzsa Gergely cikkének tárgya a rugalmas kérdöív. A rugalmas kérdőív a standard kérdőívezés érvényességének növeléséhez járul hozzá, azzal, hogy a feltett kérdésekkel kapcsolatos kommentek rögzítésével visszajelzi a válaszadói értelmezés szintjeit és rétegeit. E válaszreakciók rögzítése az eredeti kutatási kérdések és célok újragondolását is hozhatja, de egyben feltárhatja egy kérdőív második mélyebb rétegét is: „MINDEN SZOBÁT NYIT EGY $K U L C S$, és ezek a kulcsok ugyan hasonlitanak egymásra, mégis minden ajtót csak a megfelelö kulcs nyit. Létezik persze olyan kulcs is, amelyröl azt állitják, hogy minden ajtót kinyit, de ezektöl óvakodjunk: ezek az álkulcsok."

Hidegh Anna Laura cikkében a kritikai etnográfia menedzsmentkutatásban való alkalmazhatóságának szempontjairól ír. Feltárja a kutató megfigyelői szerepének dilemmáit, a résztvevő-megfigyelés technikájának és lehetőségeinek korlátait: egy adott szervezet életébe való bevonódás a kutatót a szervezeti értékrenddel, szokásokkal való azonosulásra is késztetheti - „a munkavállalók által nem kedvelt első számú vezetötöl én is távolságot tartottam, interjút sem készitettem vele" - írja, ugyanakkor a szerző felhívja a figyelmet arra, hogy a kutatónak törekednie kell, hogy a rendelkezésére álló adathalmazt ismeretlenné tegye. A kutatás végén pedig fel kell tennünk a kérdést: „ÉS AKKOR MI VAN?” (So what?), a kutató pedig intorspektív módon magának szegezheti azt a kérdést, hogy ÉS AKKOR MI VAGY?

Fekete Márta a résztvevö-rendszertérképezés módszertanát mutatja be, a mérnöki gondolkodást is alkalmazó vizualizációs módszertan előzetesen meghatározott változók (fogalmak) csoport megegyezésen alapuló kapcsolatait rögzíti. A módszer jelentősége, hogy különböző területek, diszciplínák, eltérő képzettségü képviselőinek teszi lehetővé az együttgondolkodást, GONDOLATFÜZÉST, ahol a végső eredményhez minden résztvevő hozzá tud járulni.

Sántha Kálmán triangulációról szóló cikkében, a trianguláció elméleti, módszertani, személyi és adatszintű értelmezéseit vezeti le, bemutatja, hogy miben különböznek egymástól a trianguláció és a kevert módszertanok. Nem véletlen, hogy a triangulációtipológiák leírásakor veti fel a kérdést, hogy „ÉS”, ILLETVE „VAGY” kapcsolatépítés szükséges a típusok között.

A Vezetéstudomány második kvalitatív különszáma helyet adott PIACi működés ÉS/VAGY alkalmazkodás szempontjait, marketingvonatkozásait bemutató cikkeknek. Gáti Mirkó és Bauer András a KKV-szektor marketinggyakorlatának szempontjait, Kelemen-Erdős Anikó a kiskereskedelmi versenyelöny eszközeit vizsgálta szakértői mélyinterjúk segítségével. Míg Gáti és Bauer a KKV-vezető meghatározó szerepét, MINDENHATÓSÁGÁT, Kelemen-Erdős a kiskereskedelemben folyó VERSENYT egy folyamatos, küzdelmekkel, kihívásokkal teli maraton metaforájával írja le, melynek megvalósítása, fenntartása mögött csapatmunka áll.

Nógrádi-Szabó Zoltán az akadémiai kvalitatív kutatás és a kvalitatív PIACkutatás perspektívájából hasonlítja össze a kutatói megfigyelés szempontjait - felvetve, hogy mit tanulhat a piackutatás a kulturális antropológiától, megfigyelt és megfigyelő mikor töltenek be aktív ÉS/VAGY passzív szerepeket. 